\title{
Integration of Vocal Music, Dance and Instrumental Playing in St Matthews Apostolic Church: Maphopha Congregation
}

\author{
Morakeng Edward Kenneth Lebaka \\ Department of Art History, \\ Visual Art and Musicology College of Human Sciences University of South Africa (Unisa), \\ PretoriaSouth Africa
}

\begin{abstract}
There are a number of different approaches to determining the functions of music. Members of St Matthews Apostolic church - Maphopha congregation in Sekhukhune district - Limpopo Province in South Africa identify themselves by their music and allow music to become a representation of themselves. In responding to a song, to a hymn, they are drawn into affective and emotional alliances. Their relationship to music is inevitably based upon their emotions and internal connection to a particular song. Emotionally intense songs are even used during funerals to cue specific emotions from the audience for suspense, heartbreak, or a peaceful resolution. Songs, then, become an active ingredient in their lives as they find ways to employ music as a tool to share in their life experiences and bring them to a desired emotional state. The purpose of this study was to contribute towards documenting and describing the integration of vocal music, dance and instrumental playing in this church. To achieve this aim, the study employed a naturalistic approach and data was collected through video recordings of church services, interviews and observations. The primary question the study addressed is: how is collective identity formed through music and how does religious music serve as a core part of culture? The results have shown that in this church, music is manipulated to serve congregational purposes. The investigation has also shown that identity is largely related to musical preference, and the congregants use music to understand who they are and define themselves internally as well as externally.
\end{abstract}

Keywords: St Matthews Apostolic Church; Maphopha Congregation; Limpopo Province; South Africa; Music; Identity

\section{Introduction}

In Sekhukhune district, St Matthews Apostolic church, and other independent churches such as St John Apostolic, Zion Christian (ZCC), International Pentecostal (IPC) and others have survived indoctrination and acculturation by the missionaries by insisting upon solid foundation of local traditional religious hymns. In these churches, learning music is part of the socialisation process and imitation forms an important part in the transmission process. This is an informal procedure, where people learn relevant music material through participation in pertinent activities for groups that they belong to. The transmission process involves participation, fostering of a communal sense, concentration on the present moment and the use of musico-cultural formulae and cues for interactional purposes. The learning process is largely dependent on improvisation, re-creation and variation. From this creative process, participants receive knowledge through understanding and assimilation. In St Matthews Apostolic church - Maphopha Congregation the learning process is informal, and the congregation learns the hymns through participation and imitation.

This study that focused on transference of skills among members of St Matthews Apostolic church attempted to look at the integration of vocal music, dance and instrumental playing as a process through which the congregants gain knowledge and skills necessary for worship. Further, the study looked at the association of the hymns with the ritual of the service possibly as an accompaniment to musical tradition and culture of the church. The study also sought to assess how collective identity can be formed through music. By documenting and analysing the order of church service, the internalization process and music activities in St Matthews Apostolic Church -Maphopha Congregation, the study endeavoured to reveal the modes of transmission in the teaching and learning process of the hymns, dancing and instrumental playing. The study was guided 
by the following research questions: 1) How is collective identity formed through music?; 2) How does religious music serve as a core part of culture?; 3) How effectively do the congregants learn the hymns, dancing and instruments?; and 4) How does playing traditional instruments for example, meropa (drums), mekuduetane (whistles) and dith/wath/wadi (rattles) help to instil a sense of cooperation in congregants.

\section{Theoretical Backgrround}

The present study is based on the theory of 'Praxialism' as proposed by Elliott (1995) which affords the opportunity for the integration of multi-dimensional aspects of music which is a predominant feature in the music-making processes. Elliott has convincingly argued that "indigenous African education depends considerably on rote memorization as a method of learning". Elliott's theory is supported by Oguninade (2012:109) when he writes that 'music and every aspect of life's activities are inseparable in African setting to the degree that every activity has music attached to it". Elliott highlights that the action of music should be understood in relation to the meanings and values evidenced in actual music-making and music-listening in specific cultural contexts (1995). Elliott's theory is also endorsed by Nzewi (2002:20) who asserts that "Africa perfected praxial music education", since Africans have always been actively involved in music-making instead of "non-participatory auditory encounters with music". Like in this study, the development of knowledge and performance skills in St Matthews Apostolic church - Maphopha Congregation involves a high level of music expertise including music-making, listening, improvisation, creative expertise, gestures and actions, repertoire, communal composing, imitation and choreographed dance. The acquisition of these skills is supported by informal learning which is contextual and memorybased system of learning most commonly used in Africa. This music learning approach is in consonance with this endeavour because with this approach, members of St Matthews Apostolic Church are able to succeed in meaningful and significant music-making processes for their own lives as well as the lives of others in their community. After a meticulous analysis of this model, I am convinced that St Matthews Apostolic church context is ideal for this model since, the primary function of music in this church is to promote a worship service that is culturally embedded. The theory is applicable to this study because it offers an explanation of the nature and values of music as it manifests in all cultures. In this study, the theory was used for reference while investigating the modes of transmission in the learning process of the hymns, dancing and instrumental playing. The theory also assisted in determining how collective identity is formed through music. Theoretically, the research contributes to the discussion of the relationship between the church and musical taste, genre, transmission, belief system and practices.

\section{Literary Sources and Liturgical Studies}

Written sources such as books and other sources describing the concepts of localizing and indigenizing the Christian message were consulted to establish a literature review. While articles and books by Maboee (1982); Hiltunen (1993); Van der Laar (2000) offer a broad and general information on Music and Liturgy and Africanization of liturgy, the researches and publications of Amalorpavadass (1971); Triebel (1992); Khuzwayo (1999); Hellberg (2010); Löytty (2012); Francies (2013); Kloppers (2016); Lund (2016); Murtonen (2016) provide more detailed data on the concepts localizing and indigenizing the Christian message. Scholars on the subject 'localizing and indigenizing Christian message' have done many a learned writing. In particular, Löytty (2012:138) observes that Luther worked for indigenizing the language of the Bible, the liturgy and hymns. According to him, the language as it is the core of a culture and spoken by people, is not merely the spoken words but involves many other forms of communication. He argues that music is one of them and indigenous music therefore should be included in localizing and indigenizing the Christian message. Expanding on the idea of music as a tool, Löytty (2012:188) emphasizes that music plays a central role in the dialogue between Christianity and culture by acting in a mediating role in the encounter. Löytty confidently advocates that from the side of Christian tradition, music is seen in the light of the first person of God, the Creator. He asserts that throughout centuries of Christian thinking, theologians such as Luther have claimed that music was created by God as a gift for humanity. Adding to this, Hellberg (2010:20) supports the above observations but sees 'localisation' as a wider term than indigenisation. In his view, participants in a process of localisation do not look only to the past, but also appropriate new cultural influences, using the elements of the local cultural past that still are remembered in combination with them. He argues that in a process of localising both the newly arrived elements and those that have long been present can be reshaped in various ways; the former can be localised while the latter can be modernised. Attesting to the observations above, Francies (2013:64) asserts that the Bible, never mentions a capella singing but it has much to say about musical instruments (Psalm 150). He further mentions that the Bible never says that instruments in the worship are unspiritual, nor is the practice condemned. $\mathrm{He}$ continues to argue that tradition, although helpful, cannot be elevated to the role of scripture, lest one become like the 
biblical Pharisees in the days Jesus who sought external conformity to the law with no inner substance (Francies, 2013:89). Furthermore, Francies (2013:99) suggests that congregations must feel free to disagree on non-salvation issues. He is of the opinion that every congregation must first understand its local context before it embraces ministry innovations. He candidly states that local congregations must also ask themselves, in what ways have we failed to connect with our communities and in what ways have we failed to create a community?

\section{The Perspective of this Study}

The purpose of this study was fivefold: a) to investigate and document St Matthews Apostolic Church's music of the Bapedi people, thereby contribute to the growing knowledge of religious music in Bapedi society, in Sekhukhune district; b) to investigate the modes of transmission in the learning process of the hymns, dancing and instrumental playing in St Matthews Apostolic Church; and c) to explain the integration of vocal music, dance and instrumental playing in the context of the order of church service;d) to determine the value of the music in this church and discuss its usefulness as a medium of contextualization and vehicle of communication; and e) to assess the extent to which playing traditional musical instruments for example meropa (drums), mekuduetane (whistles) and dith/wath/wadi (rattles) can instil a sense of cooperation among congregants. It is envisaged that this information will provide a clearer picture on how the congregants internalize music.

\section{Methodology and the Research Process}

The ethnographic observational data was obtained from St Matthews Apostolic Church - Maphopha Congregation, situated at Ga-Maphopha village, Sekhukhune district - Limpopo Province in South Africa. Ethnography was seen as being closest to Ethnomusicology research, a research design that attempts to understand music in the context of human behavior (Merriam, 1964). Naturalistic approach was employed, and data was collected through video recordings of church services, interviews and observations. The primary sources include oral interviews that were collected through face-to-face interaction with the interviewees, which were aimed at eliciting firsthand information on their knowledge of the subject matter. The secondary sources included among others, materials such as journal articles, books and theses. The participants in this study are from the Sepedi-speaking community. The methodology that I used in the collection of data for this study was mostly based on participant observation and interviews. In order to collect in-depth information of primary data based on naturalistic observations of church services, and what music means to the congregants in this study, an ethnographic design was used.

As the worship service in this church takes place every Sunday in the afternoon from $15 \mathrm{~h} 00$, the interviews happened on Sundays afternoon experience to capture immediate impressions. I interviewed nine (9) members of the congregation, the Pastor inclusive, ranging from ages 25-65. This large range age allowed me to capture insight of members from various generations. Each of the 9 was interviewed twice, both interviews lasting approximately forty-five (45) minutes. Due to my interest in the integration of vocal music, dance and instrumental playing in the church service, I searched for participants with related experience. With the help of the pastor, participants were sought through a selective process that prioritized diversity based on age, gender and experience in communal composing of musical activities in the church. All participants attended both interviews voluntarily and all interviews were recorded. Most of these interviews were informal and spontaneous. However, I also carried out other interviews that were longer, more formal, and in some instances taped. I also endeavoured to attend five (5) worship services, and three (3) communal composing sessions in this church that would further understanding of the modes of transmission process of their hymns. The interviews and church services provided a comprehensive picture of how collective identity is formed through music. I depended on recorded worship services, interviews and transcripts for accuracy in analyzing the data.

\section{Results}

This section presents the study findings on 'the modes of transmission in the learning process of the hymns, dancing and instrumental playing', with specific focus on St Matthews Apostolic church - Maphopha Congregation, in Sekhukhune district, Limpopo Province in South Africa. The presentations of the findings are clustered around the four research questions on which the study was anchored namely: 1) How is collective identity formed through music?; 2) How does religious music (hymns) serve as a core part of culture?; 3) How effectively do the congregants learn the hymns, dancing and instruments?; and 4) How does playing traditional instruments for example, meropa (drums), mekuduetane (whistles) and dith/wath/wadi (rattles) help instil a sense of cooperation in congregants. The aim was to assess and reveal the learning 
process of the hymns, dimensions of rhythm, the role of hand-clapping, improvisation, recreation and variation, musical repetition, musical instruments, musical creativity and musicality, the art of composing, repertoire, observation and internalization. The results were obtained from all phases: the interviews, direct observations and literature review. The results of analyzing the modes of transmission in the learning process of the hymns, dancing and instrumental playing are discussed below.

\section{Communal Composing}

\section{Learning the hymns through participation}

Learning music through participation has been a constant practice in Sekhukhune district (Lebaka, 2017:125). This is evident in St Matthews Apostolic church - Maphopha Congregation. From the observations and interviews, it was established that in St Matthews Apostolic Church, learning through participation involves communal composing (participation, repertoire and musical instruments, repetition), observation (call-and-response, coordination, gestures and actions), Imitation (performance techniques, agent and content) and choreographed dance (social tolerance, aural recall and creative product). The impression created during interviews and observations was that participants perceived that composing was not necessarily an individual process. All participants were committed to 'creative activities' which involved the relationship between music and dance. It was encouraging to observe how the participants learn more quickly and with less effort when they are enjoying themselves.

\section{Repertoire and Musical instruments}

Participants were asked about the art of composing hymns. According to Magane Michael (interview, 18 February 2018), participants are skilful in building a repertoire which is characterized by improvisation, polyrhythm, cultural blend and interlocking rhythms which compel the participants to dance to the music. The basic musical format of the hymns is fourpart harmonic setting, which allows all voices, female (soprano and alto) and male (tenor and bass), to participate in the singing, producing a feeling of communal musical expression. Repertoires are oral memory-based and the 'phrase method' was adopted in the learning process.

When asked whether the integration of traditional instruments into worship service help to instil a sense of cooperation among congregants, all the participants agreed. They felt that the integration of traditional instruments has rather encouraged maximum participation in worship service by members. Congregants feel that they are themselves. They are free to express their emotions by either clapping their hands, ululation, drumming or dancing; which is in line with the African cultural background. Masha Malebo explained (interview, 12 November 2017) that, congregants are dancing, singing from memory and worshipping God the way they like, and there is active participation in the church (see Figure 1). Mashego Ressy (interview, 21 January 2018) agrees with Masha Malebo by confirming that in Bapedi culture, music making is a communal endeavour in which cooperation between people is both a means and end. Similar to these observations, Lieberknecht $(1994: 281,283)$ rightly claims that singing in particular helps the congregation of God to recognize itself as church, so that it can establish its own identity through music and appears attractive to outsiders. Nketia (1974:15) adds that apparently the 'fact that drums and other percussion instruments were used in the Ethiopian church, which had been established in the fourth century A.D., did not affect the evangelistic prejudices'.

These observations also support Scott's (2000:9) assertion of a relationship between music and culture. He argues that, 'accepting that music is part of the experience of every human culture group, we can say that it is an inherent gift given by a wise Creator for the benefit and enjoyment for us all'. In his view, the church, in its missionary endeavours, ought to recognize and accept 'the powerful effect of music in all aspects of Christian ministry. Triebel (1992:235) endorses this observation, by stating that 'We cannot ignore culture in our missionary task'. The above observations are endorsed by Löytty (2012:17) by stating that "in many African cultures, the use of instruments is practice-specific". He further observes that their playing is regulated according to the particular cultural trading and context in where they appear.

It was further observed in this study that almost all hymns in this church are cyclical in structure, with occasional, spontaneous text, melodic and harmonic modifications. The duration of a hymn is determined by the performers' moods or preferences and the performance context: If, for example, a hymn is popular with the majority of congregants, it can go on for up to 10 minutes. An unpopular hymn, on the other, will only be sung for a matter of few minutes, before another, more appealing one is spontaneously 'announced' and 'answered'. The hymn texts are usually short, on average not exceeding ten lines. 


\section{Repetition}

Using videos, it was observed that the hymns in this church are characterized by joy, interaction, concentration, expression, self-confidence, imagination, fast tempo, and full of movement, including dance steps. This shows how much the congregants enjoy their art of worship. Musical repetition, in its simplest form is evident in the hymns. The rather simple musical nature, cyclical form of repetitiveness and basic contents, make these hymns accessible to both adults and children. As repetition of musical phrase is one of the most important compositional features in this church, it often serves as a useful means by which the singers emphasize and project to the congregation the principal idea or ideas of a particular hymn. The call and response of musical patterns usually serves as the most adequate means of creating a perpetual variation. The above observations are endorsed by Van de Laar (2000:1) when he states that "throughout history of humanity, music has played a significant role in the lives of people". According to him, music has always had an important place in the worship of God's people. He further asserts that every culture and context express itself in some way through music. He is of the opinion that since one of theology's tasks is to apply faith to the immediate context, much cannot be ignored (Van de Laar 2000:4).

\section{Observation}

\section{Call-and-response}

During observations and interviews, it was also established that all hymns in this church employ the call-and-response pattern and this pattern allows for spontaneity and self-expression. These hymns are organized into clear sections for a lead singer and a chorus. In the simplest type, each section consists of a single phrase, sung by the lead singer and answered by the chorus with a set response. This response phrase may be similar to the lead phrase. However, there are hymns in which the response section remains virtually the same while the call phrases change. The above observations are endorsed by Onyeji (2004:89) when he states that call-and-response pattern is one of the typical characteristics of African music employed by many cultures in the continent. This is also in line with the opinion of Tau Daniel (interview, 26 November 2017) who said that the dominant music making approach in St Matthews Apostolic church is rote memorization and call-and-response, and this entails drilling and verbal repetition.

\section{Coordination}

An interesting observation on the vital, if not central role of handclapping in the worship service should be mentioned. From this study, it appears that handclapping helps to maintain the tempo since some congregants gradually and habitually slowed the tempo of hymns in the course of singing. It is noticeable that when handclapping is enforced, the tempo is regularized, thereby producing a metronome effect. These observations confirm that with musical creativity and rhythmic direction, congregants build a repertoire which is characterized by cultural blend, polyrhythm, improvisation, four-part harmonic setting and interlocking rhythms which compel the congregants, the pastor inclusive to dance to the music, and hence increase attendance and participation. The above views are supported by Löytty (2012:36) who states that "in traditional African societies, music-making is generally organised as a social event". In consonance with the above views, Francies (2013:69) gives a feeling of how handclapping is perceived when he states that handclapping is an issue about which some Black congregations still struggle. He reminds us that for a long time it was seen as a violation of the scriptural mandate for worship because it was thought clapping was another form of instrumental music. To Francies, handclapping is also done in both secular and denominational settings, which made it a forbidden practice during the worship. Francies adds further insight to the understanding of handclapping by registering his concern that handclapping is seen as done for entertainment purposes and showmanship, and these practices ought not to take place in the worship service.

\section{Gestures and Actions}

An interesting dimension of this study is the creative work which is indirectly related to worship service. This developing feature is taking an increasingly important role. It is of considerable interest to note that the hymns in this church are rhythmically centred, as the drums, tambourines, whistles and rattles are the most frequently used musical instruments, not so much based on harmonic principles as Western style music. Thus, the whole congregation is usually encouraged to participate in the performance of these hymns (see figure 1), including the multi-part singing, handclapping, call-andresponse structure and dancing. Through this inviting character, these hymns serve as a communion-building, as well as communicative means. It becomes increasingly clear that the dimensions of rhythm play an important role to contextualize worship service into Bapedi cultural context. 
With regard to the use of music as a tool for spiritual motivation, the enquiry has revealed that during the order of worship service, some congregants are touched by either the scripture reading or the music or both. The above views are supported by Kubik (2001:199) who examines the relationship between music and movement. He observes that "all music in Africa is almost naturally associated with movement and action, such as playing percussion instruments, hand clapping or dancing". It is also in the same vein that Maboee (1982:131) in a careful assessment of the relationship between music and movement observes that "traditionally, when Africans worship, they sing and dance together". Maboee goes on to explain that they have a tendency to become emotionally or spiritually involved in the service'.l agree with Maboee because during my field research at Ga-Maphopha village, in Sekhukhune district, I have observed that some congregants in this church are moved by hymns, becoming spiritually motivated during the order of worship. Comments by Maboee are noteworthy because from a cultural point of view, Bapedi people tend not to be interested and comfortable in a controlled solemn church, where emotions are suppressed. Maboee's observation is applicable to St Matthews Apostolic church. During my field research, it was observed that singing in this church is always accompanied by handclapping, instrumental playing and dancing and the whole church service becomes lively because of active participation during the order of service. This is also in line with the opinion of Tshukudu Monicca (interview, 21 January 2018) when she explained that during the order of worship service, the congregants on their own, drawing upon their creative intelligence, use variation and gestures, re-creation and improvisation to make their renditions impressive.

\section{Imitation}

\section{Performance Techniques}

Ululating (mokgolokwane) plays an important role in St Matthews church service, as it does in other Bapedi cultural festivals and rituals. Culturally, it is practiced by ladies in the community and used to express utmost joy (Hiltunen, 1993:36). Hiltunen further mentions that in the past there were times when missionaries thought it belonged to pagan traditions, so it was not accepted in church at all. According to him, it was later released from the ban and became commonly used in celebrations and festivities. No arguments were found why it could not be practiced; after all, it is neutral from any religious connotations and can be considered a pure expression of joy. It colours many cultural celebrations with its high, crisp tone. Ululating has become an accepted cultural expression of praise and joy also in church, and sometimes the ladies are even requested to do it by church and parish leaders. Its inclusion in the worship service means a step forward in contextualization and adds cultural values to the liturgy (Löytty, 2012:205).

During the field research, it was observed that the creative music-making takes place during a process of interaction between the congregants' musical experience and competence, their cultural practice and their instructions. Altogether this forms the affordances in the creative situation. The impression created during interviews and observations was that the talent for composition is based on musicality, together with certain influences that have been of importance in the development of the necessary motivation and mental attitudes such as the inspiration of composer-performers. According to Madutlela Aaron (interview, 21 January 2018), the art of composing requires a reliable musical memory.

\section{Agent}

The congregants in this church believe that every individual is blessed with a voice which is unique and incomparable. To them, a good singer is expected to have a quality voice with the ability to produce it as per the requirement of the style of singing. Also, every singer should train his/her voice to make it sweet and melodious and produce a wide range of varieties of expressions. As such they prioritized rehearsals before the actual performances; either during worship services or during church rallies, circuit or diocese conferences. In their view, voice training requires commitment to regular practice, with sufficient time and devotion.

When asked if collective identity is formed through music, there was a consensus that it was the case. In particular, Senamela Masalesa (interview, 21 January 2018) mentioned that music, culture and identity are part of St Matthews Apostolic. I fully agree with Senamela Masalesa because during my field research it was difficult for me to differentiate between the choir leader and member of the choir in this church. Almost everybody can sing and dance without having received any formal tuition in either music or dancing. To them, music is an inborn talent enhanced by informal learning during the enculturation and transmission processes. Neither tonic-solfa nor staff notation is used in this church. All congregants sing from memory. The members of this church have memorised all the hymns. There are no hymn books. Through dance, the congregants have the opportunity to learn, synthesize, and demonstrate their musical ability by means 
of choreography. Through movement they can both perceive and express the meaning in their religious beliefs. In this church, musical intelligence involves its own rules and thinking structures, not necessarily linked to other kinds of intelligence, and creativity is thus manifestly a cultural process. In this church there are no separate terms for singing and dancing: 'the two are seen to be indivisible. In a way dancing is, rhythm made visible' (Karolyi, 1998:6). While singing the hymns, dancing involves rhythmic expressions, as diverse as the simple clapping of hands or stamping with the feet, expressive body movements. The careful use of figurative words with powerful associative meanings is observed in these hymns and the text possesses variation in poetic expression.

\section{Content}

Participants were asked about the role of religious music (hymns) in relation to Bapedi culture. It was found that in this church, social and ethical values are communicated through hymns, while the content is largely dictated by current concerns and the way people approach them. Passing on hymns from generation to generation or giving permission to sing them involves teaching them. Failure to understand the meaning of the lyrics is not a hindrance to learning a hymn. It is in fact rare to come across any member of any church denomination who cannot explain the meaning of what he/she sings. According to Selahle Onicca (interview, 21 January 2018), for full members of the church who are in good standing, the learning of the hymns is not a matter of personal choice, but an obligation. She further mentioned that, as most of the hymns are short and repetitive, the congregants pick up the chorus almost immediately. From these observations, it is clear that the learning of music in this church therefore, is essentially the learning of moral and ethical values. Content in the context of the church refers to knowledge, skills, attitude and values to be learnt by the congregation. It is the totality of what is to be transmitted and learnt by the congregants or church choir.

\section{Choreographed Dance}

\section{Social tolerance}

When analyzing the data material, it becomes evident that creative music-making and music identity are two sides of the same coin, in that the former provides an arena in which the latter can be explored. These observations suggest that music is part of culture and at the same time forms culture. There is a growing body of evidence to support this view. Nelson (1999:152-155) for example, provides convincing evidence of a relationship between music and culture. He advocates that "music-making in Africa is a quest for unity and integration and is directly concerned in the education of the whole person".

It is noticeable that among the congregants in this church, practice is a known and accepted fact of the musical practitioners' life, and all music practitioners say they practice, if not every day, then at least once a week. It is difficult to determine the duration of such practicing sessions, as they differ from one group to the other, but in theory, at least, it is fairly substantial, amounting to two or three hours a week at the minimum, according to the music practitioners. The learning process of the hymns reflects communal composing whereby the choir members or congregants come together to assemble communally new compositions for worship service. Individuals contribute ideas about hymn texts, polyphonic organization, melody and overall form. The choice of language usage in the hymns is encouraged by the fact that hymns are meant for communal music-making. The resulting composition is therefore their song, not a named individual. A new composition does not come from 'outside', no matter how much individual music practitioners borrow ideas and strategies from others. The compositional voice always and ultimately emanates from within. Some hymns emerge as some are abandoned. After assembling the composition, the group selects the soloist/leader.

\section{Aural recall}

This is how the participants remember music by ear. When asked whether memorizing music helps them to develop a mental map of the music, all agreed. They felt that by using their voices to sing the hymns, congregants can memorize long cycles of patterns with signals, breaks, responses, solos, etc. According to Tshehla Samuel (interview, 26 November 2017), this shows that by participating actively and creatively in music-making when needed, enables the participants to understand music artistically and contextually. Adeogun (2006: 3-63) adds further insight to the understanding of the concept 'aural-recall' in relation to musical creativity in African context, by stating that "art in any form, whether oral or not, in visual arts, music, dance, drama, mime or in the crafts, is an alternative in the imagination to the reality around human beings". Adeogun further emphasizes that music making is intended to provide understanding of self and other selves better, allowing more intelligent and meaningful action in all aspects of life. 


\section{Creative product}

Informal interviews indicated that involvement in the processes of music-making as well as music learning process in this church enables the congregants to acquire the ability to make music. Musical creativity revolves around the acquisition of skills, abilities, making musical sense and making musical meanings. It was further observed that while creative musical ability is developed to enable the congregants engage in musical interpretation in context, imaginative capacity is developed to enable the participants to experience the why, when and how to shape the on-going music performance in ways that are contextually, situationally, artistically, socially and personally significant. The results in Table 1 focus on singing, dancing and instrumental playing. Observations made on the learning process of singing, instrumental playing and dancing skills are listed and discussed below.

Table 1 summarizes the proposed modes of transmission in the teaching and learning process of the hymns, dancing and instrumental playing in St Matthews Apostolic Church - Maphopha Congregation. From the above discussion, it is pertinent to mention the fact that democratic values such as equality, tolerance and respect for everyone's dignity were upheld by all participants, and practices such as open discussion, a search for consensus, the opportunity to argue and exchange ideas until unanimity is reached are characteristic of communal learning in this church in particular, and Bapedi cultural context in general. The discussion above shows that learning by heart is a slow method, and enough repetitions in practicing eventually helped the learning process. From all of the above, originally handed down by memory-based music tradition, we can conclude that communal learning is highly valued in traditional Bapedi education and culture and rote memorization is the most effective method of learning.

\section{Discussion}

Ethnographic data from the field informs us that the question of culture is becoming very important in the worship service - whereas its consideration has been generally neglected in the past. With reference to the cultural dimensions of order of worship, it has been argued that the connection between culture and religion results in as many liturgical forms as there are cultural concepts (Chupungco, 1994:153). The findings of this study show vividly that worship service and music are instrumental in expressing one's culture, particularly in today's missionary context. The study validates that facts that, education is not only in the classroom situation; second, collective identity can also be formed through music; third, religious music can also serve as a core part of culture; and fourth, the integration of traditional musical instruments in the worship service can help to instil a sense of cooperation in congregants and assist in promoting a worship service that is culturally embedded.

The above observations are enriched by the general agreement among scholars such as Löytty (2012:117); Murtonen (2016:210); Lund (2016:245) and Hellberg (2010:25). For these scholars, music can carry with it the meaning it has been given in different kinds of situations and environments. They believe that singing could confirm identity, indicate boundaries but could also bring together different groups and erase boundaries. It is worth noting that despite fundamental and multiconsequential changes Christianity brought about in Sekhukhune district, St Matthews Apostolic church like other independent churches has used and is still using their indigenous systems of worship. Like any system of education, Bapedi traditional religious music education, is based on some kind of philosophical foundations.

The results have also shown that in this church, learning music through participation has been a constant practice.From the observations it was also established that the learning process is largely dependent on communal composing, observation, imitation and choreographed dance. In this study, however, we observe that communal music making entails the empowerment of congregants as members of the church and society, becoming socially responsible, enriching and perfecting themselves through active musical life. From the observations and interviews, it is also evident that some musical skills observed in this church are listening, performing, aural, creativity, singing and many more. When analysing the data material, it becomes evident that creative music-making and music identity are two sides of the same coin, in that the former provides an arena in which the latter can be explored.

Reviewing the results thus far, it is clear that the hymns sung in this church possess qualities quite different from Western style music, as they stress an African sense of rhythm. The message communicated by the hymns is a reflection of what is happening within contemporary Bapedi society. According to oral and literary evidence, music-making linked to religious observances, choral singing and instrumental playing forms an integral part of educational efforts (Adeogun, 2006:5-11). During interviews and observations, it was also established that the integration of vocal music, dance and instrumental 
playing in the context of worship service is traditionally not an art form separate from social and cultural meanings, connections or functions. It can be concluded from the above discussion that for making any liturgical contextualization a reality and a success, a theological knowledge and cultural understanding are required. My own evaluation during field research showed that multipart hymn singing is customary in St Matthews Apostolic church services, and the popularity of hymn singing in congregational life is functionally integrated in all spheres of church life. In view of what has been discussed above, it is clear that active participation in the preparation and actualisation of a music performance is a means by which the individuals come to draw life from it as a communal property - heritage from the past and a humanizing gift for tomorrow.

\section{Conclusion}

In conclusion, this study has revealed that music plays a crucial role in the dialogue between Christianity and culture. In view of the comments and observations established in this study, it is evident that the integration of singing, dance and instrumental playing in the context of this study could confirm identity, and communal composing is the most effective method of learning music. The study has also demonstrated that singing in own's language and worshipping God the way one wishes, contains something of one's own identity, one's own history, own culture, as well as the identity, history and culture of a group one belongs to. Indications from the investigation suggest that "to be really touched, we need to be aware of the art in what we do, and to experience a hymn as a work of art, we need to sing in a language we know, a language we understand and a language we feel" (Kloppers, 2016:82). The findings which have been presented in this study will help us to understand how creative imagination plays a very important role in cooperative learning among congregants in the learning of hymns in the church worship context.

\section{References}

[1] Adeogun, A. O. (2006). Music Education in Nigeria, 1842-2001: Policy and Content Evaluation, towards a New Dispensation. Unpublished DMus thesis, University of Pretoria, Pretoria, South Africa.

[2] Amalorpavadass, D. S. (1971). Towards indigenization in the liturgy. Dascarahalli: St. Paul Press Training School.

[3] Chupungco, A. J. (1994). Die Liturgie und Bestandteile der Kultur, in Lutherischer Welthund - Gottesdienst und Kultur im Dialog, Lutherisches Kirchenamt, (trans), A Stauffer, (ed). Evangelische Haupt-Bibelgesellschaft und von Cansteinsche Bibelanstalt in der Evangelischen Kirche der Union, 151-163.

[4] Elliot, D. J. (1995). Music matters: A new philosophy of Music Education. New York: Oxford University Press.

[5] Francies, A. L. (2013). An exploration of worship practices at an African American Church of Christ. Doctoral Dissertation, University of San Francisco.

[6] Hellberg, J. (2010). To worship God in our way: disaffection and localisation in the music culture of the Evangelical Lutheran Church in Namibia. Journal of the musical arts in Africa, Volume 7, pp. 17-50.

[7] Hiltunen, M. (1993). Good magic in Ovambo. Helsinki: The Finish Anthropology Society.

[8] Karolyi, O. 1998. Traditional African and Oriental music. London: Penguin.

[9] Khuzwayo, L. B. (1999). Bodily expressions during worship, in Minutes of Church Council No. 90, EvangelicalLutheran Church in Southern Africa (ELCSA). Kempton Park: Lutheran Church Centre, 17-19.

[10] Kloppers, E. (2016). 'My home is your home' - hymns travelling the world. In Tapani, Innanen \& Veli-Matti Salminen (eds.), Hymn, Song, Society. Helsinki, Finland: Church Research Institute.

[11] Kubik, G. (2001). Africa, in The New Grove Dictionary of Music and Musicians. Second edition. London: Macmillan I:190-210.

[12] Lieberknecht, U. (1994). Gemeindelieder - Probleme und Chancen einer kirchlichen Lebensäußerung. Göttingen: Vandenhoeck \& Ruprecht.

[13] Lebaka, M. E. K. (2017). Transmission Processes of Indigenous Pedi Music. Jyvàskylà, Finland: University Library of Jyvàskylä.

[14] Löytty, S. (2012). People's church - People's Music: Contextualization of liturgical music in an African church. Doctoral Research Project, Sibelius Academy, Helsinki, Finland.

[15] Lund, P. (2016). Spiritual songs supporting recovery from substance abuse. In Tapani, Innanen \& Veli-mati Salminen (eds.), Hymn, Song, Society. Helsinki, Finland: Church Research Institute.

[16] Maboee, C. (1982). Modimo Christian Theology in Sotho Context. Preliminary Publication. Lumko Institute: Pietermaritzburg.

[17] Merriam, A. P. (1964). The anthropology of music. Bloomington: North Western University. 
[18] Murtonen, S. (2016). Young adults and spiritually experienced music. In Tapani, Innanen \& Veli-Matti Salminen (eds.), Hymn, Song, Society, pp. 200-223. Helsinki, Finland: Church Research Institute.

[19] Nelson, D. (1999). Crossing the music threshold - Culturally atuned music fosters communion with God. Evangelical Missions Quarterly, 35(2): 152-155.

[20] Nketia, J. H. K. (1974). The Music of Africa. New York: W. W. Norton \& Company.

[21] Nzewi, M. (2002). Music education in Africa: Mediating the imposition of Western music education with the imperatives of the indigenous African practice. In C. van Niekerk (ed.), PASMEC 2001: Selected conference proceedings from the conference held in Lusaka, Zambia, 21-25 August 2001 (pp. 18-37). Pretoria: PASMAE.

[22] Ogunrinade, D. O. A. 2012. Teacher's perception on the incorporation of indigenous music contexts into music curriculum in Nigerian schools. African Journal of Education and Technology, Volume 2, No.1, pp. 108-118.

[23] Onyeji, C. (2004). Igbo rural women in Africa as creative personalities: musical processing of socio-economic solidarity. Journal of the Musical Arts in Africa.Vol. 1, 2004. 84-101.

[24] Scott, J. (2000). Tuning in to a different song - Using a music bridge to cross cultural differences. Pretoria: University of Pretoria.

[25] Triebel, J. (1992). Mission and culture in Africa - A working report on Tanzanian experience. Africa Theological Journal, 21(3):232-239.

[26] Van der Laar, J. W. (2000). A Theological Exploration of the role and use of music for worship in the Methodist church of South Africa. Unpublished MA thesis, University of South Africa, Unisa, Pretoria, South Africa.

\section{Tables}

Table 1 below shows a proposed diagram of the learning progression through participation.

\section{Communal Composing}

\begin{tabular}{|l|l|l|}
\cline { 2 - 3 } \multicolumn{2}{|l|}{} & \multicolumn{2}{l|}{} \\
\hline Participation & Repertoire \& Musical Instruments & Repetition \\
\hline $\begin{array}{l}\text { Participation differs with respect to } \\
\text { performing roles. }\end{array}$ & $\begin{array}{l}\text { Hymns/songs are tied to social ideas and } \\
\text { practices }\end{array}$ & $\begin{array}{l}\text { The singing, dancing and instrumental } \\
\text { playing are repeated innumerable times } \\
\text { until participants have mastered every } \\
\text { detail. }\end{array}$ \\
\hline
\end{tabular}

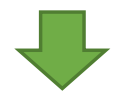

\section{Observation}

\section{Imitation}

\begin{tabular}{|l|l|}
\hline Coordination & Gestures and Actions \\
\hline $\begin{array}{l}\text { Different movements are choreographed } \\
\text { into a complete performance of singing, } \\
\text { instrumental playing and dance. }\end{array}$ & Dimensions of rhythm \\
\end{tabular}




\section{Choreographed Dance}

\begin{tabular}{|c|c|c|}
\hline Social tolerance & Aural recall & Creative Product \\
\hline $\begin{array}{l}\text { Learning through discovery. } \\
\text { Attending church services, choir } \\
\text { rehearsals, church rallies and conferences. }\end{array}$ & $\begin{array}{l}\text { Learning through demonstration and } \\
\text { memorization. } \\
\text { Internalization. }\end{array}$ & $\begin{array}{l}\text { Originality. } \\
\text { Spontaneous movements. } \\
\text { None of the dancers imitates the other. }\end{array}$ \\
\hline
\end{tabular}

Table 1: Proposed diagram of learning progression through participation.

Figures

\section{Figure 1}

St Matthews Apostolic Church: Maphopha Congregation (Ga-Maphopha village, Sekhukhune district - Limpopo Province in South Africa, 10.12.2017), Photographer: Morakeng Edward Kenneth Lebaka.

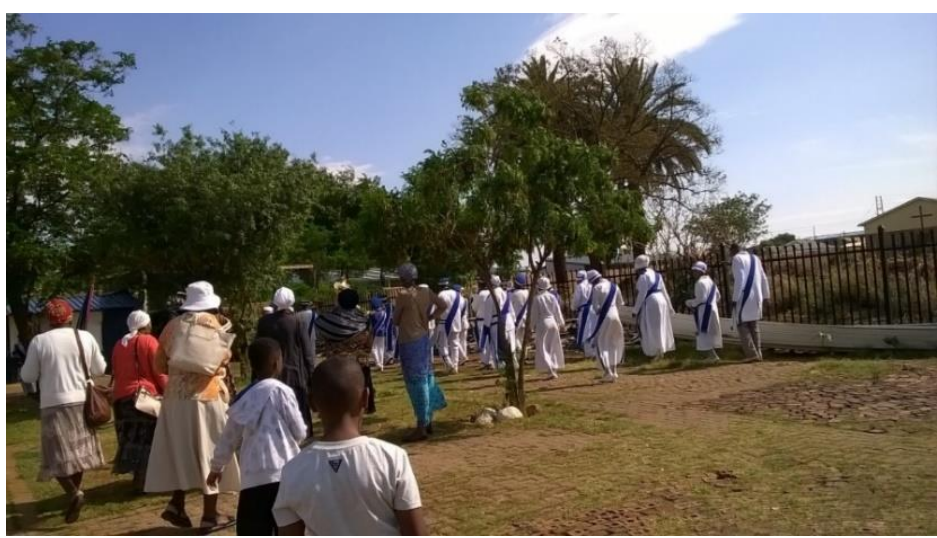

